\title{
MEMAHAMI KEMBALI RUMPUN ILMU HUKUM TATA NEGARA
}

\author{
Wiratmadinata \\ Fakultas Hukum Universitas Abulyatama, Aceh Besar \\ Jl. Blang Bintang Lama, Km. 7,5, Kuta Baro - AcehBesar \\ wiratmadinata@gmail.com
}

\begin{abstract}
The legal development that occurred resulted in the emergence of legal issues in all fields, both public and private. The same is true of the Constitutional Law, which deals not only with elections and government officials. The understanding of the law's secrets is known only to educated people but also to the commoner in understanding the nature of the law itself. Discussing the law certainly begins with philosophy by examining where it came from? What are the historical foundation, theories, and the underlying conceptual foundations? Where did the development of the science come from and what are the branches of the Law ?. This study is more specifically in the field of Constitutional Law Science which is one of the disciplines of law. The method of approach used in this study using philosophy approach and systematic approach. In this approach, the author tries to explain the position of Law, Legal Science, Constitutional Law in a structure and function of Legal Sciences.
\end{abstract}

Keywords: Understanding, Clump Science, Constitutional Law.

\begin{abstract}
Abstrak, Perkembangan hukum yang terjadi mengakibatkan munculnya persoalan hukum dalam segala bidang, baik bidang publik maupun privat. Begitu juga halnya dalam tataran Hukum Tata Negara, yang tidak hanya membahas mengenai pemilu dan pejabat pemerintahan. Pemahaman mengenai persialan hukum tersebut hanya diketahui oleh orang terdidik saja namun juga perlu diketahui bagi orang awam dalam memahami hakikat hukum sendiri. Membahas hukum tentunya dimulai dari filsafat dengan menelaah dari manakah asalnya? Apakah landasan sejarah, teori dan landasan konseptual yang melatarbelakanginya? Darimanakah asal perkembangan ilmu tersebut dan apa sajakah cabang-cabang dari IImu Hukum tersebut?. Kajian ini secara lebih khusus dalam bidang IImu Hukum Tata Negara yang merupakan salah satu Disiplin IImu Hukum. Adapun metode pendekatan yang dgunakan dalam kajian ini menggunakan pendekatan filsafat dan pendekatan sistem. Di dalam pendekatan ini penulis mencoba menjelaskan posisi Hukum, IImu Hukum, IImu Hukum Tata Negara dalam satu struktur dan fungsi rumpun-rumpun IImu Hukum
\end{abstract}

Kata kunci: Memahami, Rumpun IImu, Hukum Tata Negara.

\section{Pendahuluan}

Dalam tataran praktis, orang hanya mengenal hukum dalam konteks yang sederhana bersamaan dengan keterlibatan mereka dengan perbuatan atau persoalan hukum. Misalnya ketika orang terlibat perselisihan mengenai masalah bisnis, berupa kontrak, perkawinan, perwalian, pembentukan perusahaan, pembuatan akta-akta dan sejenisnya yang bersifat privat (pribadi) maka orang langsung memahami bahwa mereka sedang terlibat dalam urusan perdata dalam ruang lingkup Hukum Perdata (Perdata). 
Dalam khazanah ilmu hukum, hukum perdata secara umum diartikan sebagai hukum yang mengatur kepentingan perseorangan (private interest) serta mengatur hak dan kewajiban perseorangan dalam hubungan antara subjek-subjek hukum (baik antara manusia pribadi maupun dengan badan hukum perdata atau badan hukum). ${ }^{1}$

Demikian juga ketika orang menyaksikan seorang polisi menangkap seorang pencuri di televisi, atau menyaksikan langsung sebuah perkelahian, membaca berita peristiwa kekerasan, penipuan pembunuhan dan sejenisnya, maka hal itu dipahami sebagai masalah dalam ruang lingkup Hukum Pidana (Pidana). Adapun pengertian Hukum Pidana menurut Asikin, adalah keseluruhan dari peraturan-peraturan yang menentukan perbuatan apa yang dilarang dan termasuk ke dalam tindak pidana, serta menentukan hukuman apa yang dapat dijatuhkan terhadap yang melakukannya. ${ }^{2}$

Sementara itu, ketika orang berbicara tentang masalah-masalah kenegaraan ataupun terlibat,baik langsung atau tidak langsung dalam masalah Pemilihan Kepala Daerah, seperti Bupati, Walikota, Gubernur, bahkan Pemilihan Presiden (Eksekutif) dan anggota Dewan Perwakilan Rakyat atau DPR (Legislatif), serta masalah kenegaraan lainnya, orang langsung mengidentifikasikannya bahwa hal itu adalah bagian dari Hukum Tata Negara (HTN). Menurut Jimly Asshiddiqie, Ilmu Hukum Tata Negara merupakan salahsatu cabang ilmu hukum yang secara khusus mengkaji persoalan hukum dalam konteks kenegaraan. Lebih lanjut, mengutip Wirjono Projodikoro, Jimly mengatakan, kita telah memasuki bidang ilmu hukum tata negara, apabila kita membahas normanorma hukum yang mengatur hubungan antara subjek hukum orang atau bukan orang dengan sekelompok orang atau badan hukum yang berwujud negara atau bagian dari negara. ${ }^{3}$

Tetapi hal tersebut di atas hanya dipahami sebagai pengetahuan umum oleh masyarakat luas, kecuali oleh orang-orang tertentu yang terdidik, terlatih dan terlibat sebagai ilmuwan atau penegak hukum sehingga harus memahami hukum sebagai sebuah Ilmu. Orang awam merasa tidak perlu mencari tahu apakah sebenarnya hakikat hukum itu secara lebih mendalam. Tetapi bagi mereka yang menuntut Ilmu Hukum, harus mencari tahu Apakah sebenarnya hukum? Bagaimana hukum itu bekerja? atau apakah sebenarnya fungsi hukum tersebut?. Refleksi kritis-sistematis terhadap landasan kefilsafatan, sifat dan ciri-ciri keilmuan serta bangunan fisik (struktur) Ilmu Hukum itu termasuk kedalam disiplin filsafat ilmu. Artinya pertanyaan-pertanyaan seperti diatasitu sebenarnya masuk dalam kerangka pertanyaan filsafat ilmu. ${ }^{4}$

Bagi para sarjana, ilmuwan atau mahasiswa yang sedang memperdalam Ilmu Hukum, mereka tidak hanya harus memahami hukum sebagai pengetahuan, tetapi juga sebagai ilmu. Bahkan tidak cukup memahami substansi ilmunya, para mahasiswa juga harus tahu dimanakah posisi keilmuan dari objek yang sedang dan akan mereka teliti di dalam kerangka rumpun ilmu secara luas, termasuk juga dalam konteks rumpun Ilmu

\footnotetext{
${ }^{1}$ Zainal Asikin, Pengantar Tata Hukum Indonesia. (Jakarta: Rajawali Press, 2013), hlm. 95

${ }^{2}$ Ibid. hlm. 103.

${ }^{3}$ Jimly Asshiddiqie. Pengantar Ilmu Hukum Tata Negara, (Jakarta: Rajawali Press, 2013), hlm 12-13.

${ }^{4}$ Bernard Arief Sidharta, Refleksi Tentang Struktur Ilmu Hukum (Disertasi), (Bandung: Mandar Maju, 2000), hlm. 31
} 
Hukum itu sendiri secara khusus. Para mahasiswa harus menelusuri akar, fondasi, struktur, sistem dan sumber dari Ilmu Hukum tersebut. Oleh karena itu mereka harus dapat menggambarkan kerangka "rumpun ilmu" dari Ilmu Hukum yang sedang ditelitinya. Dalam program Doktoral, atau Strata tiga (S3), pada Program Pascasarjana, Fakultas Hukum Universitas Syiah Kuala, mata kuliah "Seminar Rumpun Ilmu" diwajibkan pada semester-II sebagai salahsatu syarat yang harus dipenuhi dalam program tersebut. ${ }^{5}$ Dalam konteks inilah, makalah ini disusun oleh penulis dengan judul: "Kajian Konsep Negara Hukum Pancasila dalam Kerangka Rumpun Ilmu Hukum”.

Terkait dengan pemaparan pada bagian awal latar belakang diatas, persoalan yang pokok bagi seseorang yang sedang berusaha memperdalam pemahaman Ilmu Hukum pada tingkat doktoraladalah, untuk mengetahui dimanakah posisi keilmuan dari Ilmu Hukum yang sedang mereka pelajari ditengah-tengah ilmu lainnya. Meskipun seseorang telah menguasai hukum dalam praktik, tetapi belum tentu mereka memahami akar-akar kefilsafatan Ilmu Hukum itu sendiri; dari manakah asalnya? Apakah landasan sejarah, teori dan landasan konseptual yang melatarbelakanginya? Darimanakah asal perkembangan ilmu tersebut dan apa sajakah cabang-cabang dari Ilmu Hukum tersebut. Pada tingkat yang lebih mendalam penyelidikannya termasuk pada titik manakah posisi kajian hukum yang sedang dikaji; misalnya, jika penulis ingin membuat "kajian tentang negara hukum pancasila", maka pertanyaan yang muncul dalam konteks ini adalah; dimanakahposisi keilmuan kajian tersebut di dalam Ilmu Hukum? Jika misalnya; ternyata kajian tersebut termasuk masuk kedalamKajian Hukum Tata Negara, apakah dia masuk kedalam Hukum Tata Negara Khusus atau yang Umum? Apakah hubungan kajian ini dengan Hukum Konstitusi dan Perundang-Undangan, hukum Administrasi Negara dan seterusnya? Termasuk juga bagaimanakah hubungan antara objek ilmu hukum yang dikaji dengan ilmu lainnya, seperti Ilmu Sosial, Ilmu Politik dan Ilmu Ekonomi, Sosiologi serta antropologi, dan seterusnya. ${ }^{6}$ Disinilah pusat permasalahan dalam kajian "Seminar Rumpun Ilmu" dalam sudut pandang penulis, dan menjadi fokus pembahasan di dalam makalah ini.

Dalam konteks penulisan makalah ini, selain mengkaji kembali pemahaman mengenai Hukum dan Ilmu Hukum dalam kerangka Rumpun Ilmu baik secara umum maupun secara khusus mengenai Rumpun Ilmu Hukum, penulis mengarahkan kajian secara lebih khusus dalam bidang Ilmu Hukum Tata Negara yang merupakan salahsatu Disiplin Ilmu Hukum, atau sering juga disebut dengan Bagian atau Konsentrasi Ilmu Hukum Tata Negara. Pilihan ini tentu tidak terlepas dari Disiplin Keilmuan yang diperdalam oleh penulis sebagai Mahasiswa Program Doktor Ilmu Hukum dengan konsentrasi Ilmu Hukum Tata Negara (HTN). Sementara itu alasan yang lebih praktis lainnya adalah, penulisan makalah ini terkait dengan rencana penelitian Proposal Disertasi (tentative) penulis yang berjudul; "PARADIGMA NEGARA HUKUM PANCASILA DAN IMPLIKASINYA TERHADAP SISTIM HUKUM NASIONAL INDONESIA".

${ }^{5}$ Lihat kurikulum Program Studi Pascasarjana, Doktor Ilmu Hukum (DIH), Fakultas Hukum, Universitas Syiah Kuala, Darussalam, Banda Aceh, tahun ajaran 2015/2016, Semester-II.

${ }^{6}$ Valerine JLK., Metode Penelitian Hukum, Diktat Kuliah Pascasarja, Fak. Hukum UI, 2009, (Untuk kalangan sendiri, tidak diperjual belikan), 2009, hlm. 11. 
Sebelum memperdalam kajian sebagaimana tersebut di atas sebagai sebuah tentative Penelitian Ilmiah Program Doktor, maka dipastikan sangat perlu untuk memperdalam atau menggali lebih detail lagi, untuk mendapatkan pemahaman lebih menyeluruh mengenai posisi Ilmu Hukum dalam kerangka rumpun ilmu. Selanjutnya, setelah berhasil menemukan posisi Ilmu Hukum dalam kerangka ilmu, perlu diketahui cabang disiplinnya, apakah termasuk ke dalam Disiplin HTN, Pidana atau Perdata dan seterusnya, hingga cabang, ranting dan pucuknya yang terkecil.Untuk lebih spesifik, mengenai apakah fokus dari seluruh latarbelakang permasalahan yang telah dirumuskan ini, penulis mencoba menyusunkerangka pertanyaan penelitian pada bagian Perumusan Masalah.

Adapun perumusan masalah yang penulis ajukan berdasarkan latar belakang di atas adalah sebagai berikut;

1. Apakah yang dimaksud dengan Hukum dan Ilmu Hukum dalam Rumpun Ilmu?

2. Bagaimana Struktur Ilmu Hukum dalam kerangka Rumpun Ilmu?

3. Bagaimana Posisi Kajian Paradigma Negara Hukum Pancasila dalam Rumpun Ilmu Hukum?

\section{Metode Pendekatan}

Untuk dapat melakukan kajian secara lebih terfokus, spesifik dan relevan terhadap objek yang dibahas di dalam penelitian ini, maka penulis mencoba menelaahnya melalui dua pendekatan, yakni;

Pendekatan Filsafat Ilmu; khususnya Epistemologi Hukum; Pendekatan ini pada dasarnya adalah kajian mengenai Hukum sebagai sebuah Ilmu berbasis pertanyaan mendasar; Apakah Hukum itu ilmu? Jika memang ilmu, maka tahap selanjutnya yang harus diketahui seperti apakah Struktur Ilmu Hukum tersebut. Dengan membahas hal tersebut pada tahap selanjutnya maka akan diketahui Rumpun Ilmu Hukum. Untuk itu, penulis menggunakan kerangka analisis berdasarkan Epistemologi Ilmu atau Filsafat Tentang Ilmu Pengetahuan, dalam hal ini adalah Ilmu Hukum.

Pendekatan Sistim; Pendekatan ini pada dasarnya mencoba melihat hukum dalam kerangka hukum sebagai suatu sistim yang teratur, dimanadidalamnya juga terdapat struktur dan fungsi-fungsi sebagai sub-sistim yang saling terkait dan memiliki tujuan, dalam hal ini tujuan hukum. Di dalam pendekatan ini penulis mencoba menjelaskan posisi Hukum, Ilmu Hukum, Ilmu Hukum Tata Negara dalam satu struktur dan fungsi rumpun-rumpun Ilmu Hukum.

\section{Kerangka Teori}

\section{Ilmu Hukum dalam kerangka Filsafat Ilmu:}

Menurut Sumantri, Filsafat Ilmu merupakan bagian dari epistemologi (filsafat pengetahuan) yang secara spesifik mengkaji hakikat ilmu (Pengetahuan ilmiah). Ilmu merupakan cabang pengetahuan yang mempunyai ciri-ciri tertentu. Meskipun secara metodologis ilmu tidak membedakan antara ilmu-ilmu alam dengan ilmu-ilmu sosial, namun karena permasalahan teknis yang bersifat khas, maka filsafat ilmu ini sering dibagi menjadi filsafat ilmu-ilmu alam dan filsafat ilmu-ilmu Sosial. Pembatasan ini lebih 
sering merupakan pembatasan masing-masing bidang yang ditelaah, yakni Ilmu alam atau Ilmu sosial dan tidak mencirikan cabang filsafat lainnya yang bersifat otonom. Ilmu memang berbeda dari pengetahuan pengetahuan secara filsafat namun tidak terdapat perbedaan yang prinsip antara ilmu-ilmu alam dengan ilmu-ilmu sosial, dimana keduanya mempunyai ciri keilmuan yang sama. ${ }^{7}$

Untuk memahami Hukum sebagai Ilmu maka dia harus dikaji berdasarkan pendekatan Filsafat Ilmu untuk mendapatkan jawaban tentang; Objek apa yang ditelaah oleh ilmu? (Ontologi). Bagaimana proses yang memungkinkan ditimbanya pengetahuan? (Epistemologi) dan Untuk apa pengetahuan yang berupa ilmu pengetahuan itu dipergunakan? (Aksiologi) Semua pengetahuan apakah itu ilmu, seni, atau pengetahuan apa saja pada dasarnya mempunyai ketiga landasan ini. Yang berbeda adalah materi perwujudannya serta sejauh mana landasan-landasan dari ketiga aspek filsafat diatas dikembangkan dan dilaksanakan. ${ }^{8}$ Dengan demikian, maka kita dapat dengan mudah memahami konsep keilmuan hukum termasuk sistim dan struktur Ilmu hukum berdasarkan telaah terhadap ketiga aspek filsafat tersebut di atas.

Secara lebih spesifik, sebagai kerangka teori, jika dikaitkan dengan Ilmu Hukum, maka kita dapat mendekati pemahaman Rumpun Ilmu Hukum dengan menggunakan pertanyaan;

1. Objek apa yang ditelaah oleh Ilmu? (Ontologi); Kita terjemahkan dengan pertanyaan; Apa yang ditelaah oleh Ilmu Hukum? Atau Apakah Ilmu Hukum itu?

2. Bagaimana proses yang memungkinkan ditimbanya pengetahuan? (Epistemologi); Kita terjemahkan dengan pertanyaan; Bagaimana proses munculnya atau hadirnya Ilmu Hukum itu ditengah masyarakat?

3. Apakah kegunaan dari Ilmu Hukum tersebut? (Aksiologi); Kita terjemahkan dengan pertanyaan; Apakah guna atau tujuan dari Ilmu Hukum tersebut).

Sementara itu, menurut Susanto, Epistemologi merupakan cabang filsafat yang membicarakan mengenai sumber-sumber, karakteristik, sifat dan kebenaran pengetahuan. Epistemologi seringkali disebut dengan teori pengetahuan atau filsafat pengetahuan, karena yang dibicarakan epistemologi ini berkenaan dengan hal-hal yang ada sangkut pautnya dengan masalah pengetahuan. Misalnya apakah itu pengetahuan? Dari mana asalnya? Apakah sumber-sumber pengetahuan? Apa yang menjadi karakteristik pengetahuan? Termasuk juga apakah pengetahuan itu sudah benar atau keliru? Beberapa pertanyaan inilah yang sering disebut dengan "persoalan epistemologi". Oleh karena itu, upaya menjawab pertanyaan Rumpun Ilmu Hukum pada hakikatnya adalah usaha yang terkait dengan "persoalan epistemologi". ${ }^{9}$ Sehingga dengan melakukan pembahasan dan kemudian memberikan jawaban terhadap ketiga pertanyaan epistemologi tersebut, maka dengan sendirinya kita akan memasuki wilayah rumpun keilmuan dari Ilmu Hukum; Dari manakah asalnya, apakah hakikatnya, dan apakah cabang-cabangnya.

7 Jujun. S. Suriasumantri, Filsafat Ilmu Sebuah Pengantar Popular, (Jakarta: Sinar Harapan. 2005), hlm. 35 .

${ }^{8}$ Ibid. hlm. 33.

9 A. Susanto, Filsafat Ilmu: Suatu Kajian Dalam Dimensi Ontologis, Epistemologis dan Aksiologis. (Jakarta: Bumi Aksara, 2011), hlm. 135. 
Dengan demikian, kita juga akan memasuki struktur Ilmu Hukum yang terbentuk dari suatu proses filsafat keilmuan itu sendiri. Untuk itu, kerangka pendekatan teori di atas perlu dilengkapi dengan kerangka teori lainnya, yaitu Teori Sistim yang selanjutnya difahami sebagai Teori Sistim Hukum. Karena pada hakikatnya, usaha memahami Rumpun Ilmu Hukum, sama halnya dengan memahami sistimnya.

\section{Ilmu Hukum dalam kerangka Teori Sistem:}

Teori Sistim, pada dasarnya adalah suatu studi antar-disiplin dari suatu sistim yang umum dengan tujuan utamanya menemukan pola-pola dan menjelaskan prinsip-prinsip yang bisa diaplikasikan terhadap bentuk sistim dalam semua cabang ilmu. Penemu teori ini adalah Karl Ludwig von Bertalanffy (1901-1972), seorang biologist dari 'austria dan dikenal sebagai penemu GST "Teori Sistim Umum (General System Theory). Aslinya teori ini dimaksudkan untuk menjelaskan sistim yang terkait dan saling berinteraksi dengan komponen-komponen lainnya dan diaplikasikan dalam ilmu bilogi dan cybernetics, serta sistim lainnya. ${ }^{10}$

"Systems theory is the interdisciplinary study ofsystems in general, with the goal of Discovering pattern sandelucidating principles that can be discerned from, and applied to, alltypes of system satallnesting levels in all field sof research. Systems theory can reasonably be considered a specialization of systems thinking or as the goal output of systems sciencen and system sengineering, with an emphasis on generality useful across a broad range of systems (versus the particular models of individual fields). A central Topic Of Systems Theory Is self-regulating systems, i.e. systems self-correcting through feedback. Self-regulating systems are found in nature, including the physiological systems of our body, in localand global ecosystems, and in climate-and in human learning processes (from the individual on upthrough international organizations like the UN). ${ }^{11}$

Pengaruh teori sistim ini banyak kita temui dalam berbagai cabang ilmu lainnya, dengan perkembangan yang khusus, misalnya di dalam Ilmu Hukum kita mengenal Teori Sistim Hukum, di dalam Ilmu Sosial dan Politik kita mengenal Teori-Struktural fungsional yang isi penjelasannya tidak banyak berbeda. Scara umum yang dimaksud dengan sistim adalah; Suatu rangkaian yang terdiri sub-sistem, komponen, bagian dan cabang-cabang, yang saling terkait dan berhubungan satu dengan yang lainnya serta saling mempengaruhi dalam suatu keseimbangan yang memiliki tujuan tertentu.

Dalam kaitan makalah ini, sesuai dengan penjelasan teori sistim diatas dari Bertallanffy, teori itu digunakan sebagai pisau analisis untuk menjelaskan Rumpun Ilmu Hukum berdasarkan penjelasan Struktur Ilmu Hukum guna menggambarkan posisi Ilmu Hukum, akar, bagian-bagian dan komponennya, sebagai suatu sistim yang saling terkait, tersusun dan saling berhubungan dalam susunan kerang Rumpun Ilmu yang teratur dan rapi.

\footnotetext{
${ }^{10} \mathrm{http}: / /$ www.panarchy.org/vonbertalanffy/systems.1968.html.

${ }^{11} \mathrm{https} / / /$ en.wikipedia.org/wiki/Systems_theory
} 


\section{Pembahasan}

\section{Hukum dan Ilmu Hukum dalam Kerangka Rumpun Ilmu. \\ 1) Hukum Sebagai PengertianHukum.}

Untuk memulai telaah tentang Rumpun Ilmu dari Ilmu Hukum, maka mau tidak mau harus dimulai dari pemahaman dasar atas pengertian dari terminologi Ilmu Hukum itu sendiri. Secara etimologi; Ilmu Hukum terdiri dari dua kata, yakni "Ilmu" dan "Hukum", yang masing-masing memiliki arti tersendiri yang terpisah. Demikian juga saat kedua kata itu dijadikan satu dan menjadi terminologi; Ilmu Hukum; maka kedua kata itu membentuk suatu pengertian yang khusus dengan makna yang baru pula. Dalam suatu kajian ilmiah, sudah lazim untuk memberikan penjelasan terhadap istilah-istilah tertentu yang kemudian disebut dengan terminologi ilmiah agar ada kesamaan pandangan, antara penulis dan pembaca tentang kata-kata kunci dari topik yang sedang dibahas. Oleh karena kajian ini adalah tentang Rumpun Ilmu dari Ilmu Hukum (Rumpun Ilmu Hukum), penulis akan memulainya dengan mengupas makna kata Ilmu, Hukum dan Ilmu Hukum itu secara terpisah terlebih dahulu, sebagai pengantar untuk pembahasan lanjutan yang lebih substantif.

Menurut Soeroso, setidaknya ada empat istilah mengenai hukum yang biasa digunakan di dalam kajian Ilmu Hukum, yaitu kata Hukum itu sendiri, yang berasal dari bahasa "Arab" yang merupakan bentuk tunggal, sementara bentuk jamaknya adalah "Alkas" yang berkaitan dengan makna; yang dapat melakukan paksaan. Di dalam Bahasa Belanda, Hukum disebut "Recht" yang berasal dari kata "Rectum" (latin) yang berarti bimbingan, tuntutan atau pemerintahan. Kata ini terkait dengan kata "Rex' yaitu orang yang pekerjaannya memberikan bimbingan atau memerintah. Kata "Rex" juga dapat berarti "Raja" yang memiliki pasukan dan bermakna kerajaan. Sementara kata "Rectum" dapat juga dihubungankan dengan kata "Directum" yang artinya orang yang memiliki pekerjaan membimbing atau mengarahkan. Kata-kata yang memiliki arti serupa dengan ini adalah; Directur atau Rector. ${ }^{12}$ Jika diperhatikan semua kalimat tersebut terkait dengan apa yang kita pahami secara umum saat mendengar kata hukum dalam Bahasa Indonesia.

Istilah lainnya adalah "Ius" (latin) yang berarti hukum, diambil dari kata "Iubere" yang bermakna mengatur atau memerintah. Konotasi dari kata ini mengandung makna "kewibawaan". Kata Ius sering juga disebut dengan kata yang mirip, yaitu "Iustitia (sering dimengerti dengan kata; Justisia dalam ejaan Indonesia) yang berarti "keadilan". Orang Yunani menabalkan nama Iustitia pada seorang Dewi yang berarti Dewi Keadilan. Kata lain yang bermakna hukum dalam Bahasa Latin adalah; " Lex" yang berasal dari kata "Lesere" dan bermakna mengumpulkan orang-orang untuk diberi perintah dan mengandung pengertian wibawa atau otoritas (perintah). ${ }^{13}$

Kembali pada pertanyaan pada awal tulisan ini, apakah sesungguhnya yang dimaksud dengan hukum?. Sampai saat ini belum ada satu kesepakatan definisi tunggal mengenai pengertian Hukum. Hal itu bukan hanya karena sulit, tetapi hampir tidak mungkin membuat satu definisi yang dapat menampung seluruh pengertian mengenai apa

${ }^{12}$ Soeroso. Pengantar Ilmu Hukum, (Jakarta: Sinar Grafika, 2011), hlm. 24-26.

13 Ibid. 
itu hukum?. Hal itu disebabkan karena Hukum adalah masalah yang sangat kompleks, luas dan mungkin rumit. Ia memiliki banyak segi, aspek dan bentuk. Oleh karena begitu luasnya wilayah cakupan masalah kehidupan yang dimasuki oleh Hukum, sehingga para sarjana mengalami kesulitan untuk membuat satu definisi saja mengenai apa itu hukum. Sehingga kalaupun mereka membuat sebuah definisi, maka itu akan berbeda antara satu dengan yang lain. Bukan karena definisi itu salah, tetapi karena tidak ada definisi yang berhasil mencakup seluruh hakikat pengertian dari hukum tersebut. Itulah sebabnya semua buku-buku teks hukum yang ingin menjelaskan apa itu hukum hanya bisa menyajikan beberapa pandangan sarjana-sarjana terpilih, baik klasik maupun modern, sehingga pembaca dapat mengambil pengertiannya sendiri. Orang bisa memahami pengertian apa itu hukum secara bertahap dari sudut-sudut pandang masalah tertentu atau dari sudut pandang sarjana tertentu. Kenyataan ini sama sekali tidak berkaitan dengan keterbatasan ilmu para sarjana, tetapi lebih karena begitu luasnya cakupan Hukum tersebut.

Van Appeldorn sendiri mengatakan, jika ada orang bertanya kepadanya apakah sebenarnya hukum maka ia akan menjawab: "Tidak dapat saya katakan begitu saja, karena satu sama lain berlainan. Sehingga tidak dapat saya menyatukannya dalam sebuah kalimat. Dengan memperhatikan undang-undang saja pun kita sudah dapat memungut pelajaran bahwa tidaklah mungkin memberikan definisi tentang hukum yang dapat menyatakan isinya". ${ }^{14}$ Dari apa yang disampaikan Van Appeldorn, fahamlah kita bahwa memahami apakah hukum itu sebenarnya, tidak bisa berdasarkan definisi dari satu atau dua sarjana, demikian juga dari satu atau dua sudut pandang. Memahami apa itu hukum adalah dengan memasuki hukum itu sendiri. Analoginya adalah: Kita tidak bisa mengetahui apa itu definisi gunung secara lengkap, apabila kita tidak mendaki gunung tersebut.

Hukum pada dasarnya adalah suatu konstruksi berfikir ${ }^{15}$ manusia yang muncul bersamaan dengan berkembangnya manusia sebagai suatu kelompok yang terdiri dari individu-individu yang disebut dengan masyarakat (society). ${ }^{16}$ Terbentuknya masyarakat diawali dari adanya individu-individu baik lelaki maupun perempuan (human being) yang kemudian menjalin relasi sosial dan biologis sesuai kodratnya sebagai makhluk hidup

\footnotetext{
${ }^{14}$ Van Appeldorn, Pengantar Ilmu Hukum (inleiding tot de studie van het nederlandserecht), Terjemahan Mr. Oetarid Sadino). (Jakarta: PradnyaParamita, 2011), hlm. 2.

${ }_{15}$ Pengertian "konstruksi berfikir" ini merupakan upaya penulis untuk mengakomodir keaneka ragaman pendapat mengenai apa itu; Hukum?, yang menurut berbagai sarjana klasik dan modern sulit untuk didefinisikan, dan tidak ada keseragaman diantara para sarjana tentang mengenai hal ini. Di dalam buku-buku teks Pengantar Ilmu Hukum biasanya disajikan beragam pendapat para ahli dan sudut pandang pengertian tertentu tentang apa itu hukum; tanpa ada satu definisi baku. Oleh karena itu, penulis menyebut keragaman ini dengan kata "konstruksi berfikir".

${ }_{16}$ Mengenai terbentuknya suatu masyarakat, dapat dilihat pada teori-teori Artistoteles yang menjelaskan tentang proses terbentuknyasuatu masyarakat, juga di dalam buku Filsafat, sosiologi, dll. Dalam buku teks hokum bias dilihat misalnya; karyaSoehino, dalam Ilmu Negara, (Yogyakarta: Liberty, 2002), hlm. 25, dimana Aristoteles menyebut istilah "Zoon Politicon" dan Teori Organisme, tentang terbentuknya Negara, dimana Negara pada dasarnya adalah seperti keluarga besar yang terdiri dari individu, keluarga, klan, suku, bangsa dan kemudian membentuk Negara.
} 
dalam sistim hukum alam ${ }^{17}$ (natural law atau sunatullah). Relasi sosial dan biologis manusia itu kemudian melahirkan apa yang disebut dengan keluarga (family) sebagai sarana berkembangnya masyarakat yang menghasilkan lebih banyak individu-individu baru dan keluarga baru. Keluarga-keluarga dari satu rumpun keturunan kemudian terbentuk sebagai suatu "kaum" atau kelompok keluarga dalam satu rumpun atau suku, dan kemudian kumpulan suku-suku akan membentuk suatu bangsa. ${ }^{18}$

Dengan cara demikian manusia berkembang sebagai makhluk sosial atau masyarakat. Bersamaan dengan berkembangnya masyarakat ini muncul kebutuhan untuk mengatur hidup bersama, agar mereka bisa hidup teratur dalam suatu sistim. Dalam konteks inilah hukum hadir ditengah-tengah manusia. Jadi dapat dikatakan, pada dasarnya hukum lahir bersamaan dengan berkembangnya masyarakat itu sendiri. Bahkan secara lebih mendalam lagi dapat dikatakan bahwa hukum identik dengan masyarakat. Itulah sebabnya muncul suatu adagium yang berbunyi: "ubi societas, ibiius" yang bermakna, "dimana ada masyarakat disitu ada hukum". Istilah ini dikemukakan oleh Marcus Tullius Cicero (Cicero) (106-45 SM) dalam dua karyanya yang terkenal De Republica (Tentang Politik) dan De Legibus (Tentang Hukum). Kesimpulan yang dikemukakan Cicero tentang relasi antara hukum dan masyarakat itu menjelaskan kepada kita bahwa hukum merupakan suatu konstruksi logis dari keberadaan manusia sebagai suatu masyarakat. Sehingga dapat dikatakan, tidak mungkin sebuah masyarakat bisa hidup teratur dalam satu sistim sosial ${ }^{19}$ tanpa adanya aturan-aturan, atau tata-cara berperilaku, yang bisa berfungsi mengatur hidup mereka yang dipenuhi oleh berbagai macam persoalan sebagaimana kodratnya manusia. Persoalan tersebut mulai yang sifatnya domestik (privat) atau yang sifatnya umum (publik), sehingga isi dari hukum itu sendiri secara garis besar dapat dibagi ke dalam Hukum Publik dan Hukum Privat. ${ }^{20}$

Selain itu, sebagaimana yang sudah disinggung diatas, masyarakat pada dasarnya memiliki sistimnya sendiri yang disebut dengan sistim sosial, sebagaimana dikatakan TalcottParsons, sistim ini mengatur peran dan fungsi setiap lapisan, dan struktur dari masyarakat itu, baik secara horisontal maupun vertikal, dan sistim itu baru berfungsi apabila masyarakat tersebut telah membentuk hukumnya sendiri. Misalnya, fungsi lembaga adat, lembaga agama, lembaga pendidikan, dan seterusnya. Jadi manusia sejak awal terbentuknya sudah membutuhkan hukum untuk mengatur hidupnya sebagai suatu

${ }^{17}$ Dalam masyarakat Islam, Hukum Alam difahami sebagai kodrat, yaitu prinsip sebab-akibat yang sifatnya alamiah yang sifatnya tetap dan difahami sebagai ketentuan alam semesta yang diatur oleh suatu zat yang maha kuasa yang disebut dengan Allah atau Tuhan semesta alam. Dan masyarakat difahami sebagai kodrat alam. Menurut Aristoteles, masyarakat itu terbentuk karena kehendak dari Budi Illahi.

${ }^{18}$ Aristoteles, Politik, (Bandung: Buku Seru, 2016), hlm. 10

${ }^{19}$ Soetomo, Masalah Sosial dan Upaya Pencegahannya, (Yogjakarta: Pustaka Pelajar, 2008), hlm. 51. Sistim Sosial mengacu pada teori sosiologi dan digunakan dalam Ilmu Politik; Teori Struktural Fungsional yang dikembangkan oleh Talcott Parsons yang menggambarkan bahwa masyarakat itu pada dasarnya terdiri dari struktur dan fungsi dalam suatu sistim, dimana setiap sub-sistem saling berhubungan dan tergantung satu sama lain dalam suatu keseimbangan untuk mencapai tujuan dari masyarakat tersebut. Dalam konteks hukum, relasi-relasi antara kelompok social, lembaga social dan lain-lain diatur oleh suatu norma atau aturan yang disebut hukum.

${ }^{20}$ C.S.T. Kansil. Pengantar Ilmu Hukum dan Tata Hukum Indonesia, (Jakarta: Balai Pustaka, 1989), hlm. 75. 
kelompok, bagian dari kelompok terkecil yaitu keluarga. Di dalam keluarga terdapat hukum yang mengatur peran dan fungsi setiap individu dan bagaimana mereka berinteraksi satu sama lain berdasarkan aturan yang sudah disepakati. Pada dasarnya substansi dari kehadiran aturan atau norma yang kemudian disebut dengan hukum adalah karena adanya yang disebut dengan perilaku atau tindakan-tindakan yang dilakukan oleh manusia, baik secara individual maupun kelompok. Hukum mengatur perilaku tersebut karena tindakan atau perilaku satu individu di dalam kelompok dapat mempengaruhi keadaan individu atau kelompok lainnya, baik itu secara positif atau secara negatif. Jika tindakan itu bersifat positif dalam arti menguntungkan individu lainnya atau kelompok lainnya mungkin tidak ada masalah, tetapi jika tindakan itu bersifat negatif atau cenderung merugikan individu atau kelompok lainnya maka disitu akan timbul masalah. Oleh karena itu, hukum harus hadir untuk menjamin adanya harmoni atau ketenteraman di antara semua orang di dalam masyarakat.

Konstruksi berpikir hukum ini, sebagaimana kita singgung pada bagian awal seperti yang dikatakan SoerjonoSoekanto, dimulai sejak seseorang masih kecil dan kemudian berkembang semakin dewasa dan dia menyadari bahwa meskipun dia memiliki kebebasan untuk melakukan apa yang diingininya, tetapi tidak boleh berbuat semaunya. Dari kedua orang tuanya, seseorang mendapatkan didikan untuk mengetahui tindakantindakan yang boleh dilakukannya dan tindakan-tindakan yang terlarang. Hal ini kemudian berkembang menjadi semacam kesadaran di dalam diri manusia, bahwa kehidupan di dalam suatu masyarakat pada dasarnya berpedoman pada seperangkat aturan yang harus dipatuhi karena merupakan pegangan bagi keteraturan hidup mereka. ${ }^{21}$

\section{2) Hukum Dalam Pengertian Ilmu :}

Meskipun manusia sejak awal kehadirannya dibumi sudah membutuhkan hukum, tetapi bukan berarti mereka sudah memahami atau menguasai Hukum sebagai Ilmu. Makna dan pengertian Hukum sebagai Ilmu adalah dua hal yang sangat berbeda. Jika pada bagian terdahulu kita membahas hukum sebagai suatu pengertian tentang hukum itu sendiri, sebenarnya kita melihat dari sudut pandang makna kata hukum secara bahasa (etimologi). Tetapi ketika kita ingin membahas hukum sebagai sebuah ilmu, maka dia harus dilihat dari sudut Filsafat Ilmu.

Jika seseorang mengetahui sesuatu sebagai sebuah pengalaman, atau pengetahuan yang diperoleh dari berbagai sumber, misalnya dari mulut ke mulut, dari cerita orang lain, radio, televisi, majalah dan bahkan buku-buku secara terpisah, pada dasarnya seseorang memahami sesuatu sebagai pengetahuan semata. Orang yang memahami hukum dengan cara seperti diatas, pada dasarnya memiliki pengetahuan (knowledge) tentang hukum, tetapi bukan berarti dia menguasai Ilmu Hukum. Pengetahuan tentang hukum secara acak dan bukan sebagai Ilmu, meskipun sangat luas, tetapi tidak teratur, tidak sistimatis, dan mungkin difahami secara tidak logis atau berdasarkan logika.

Hal ini berbeda jika seseorang mengetahui hukum karena ia mempelajarinya secara sistematis, dan berada dibawah arahan para ahli pada bidang yang bersangkutan. Selain itu, untuk memperoleh Ilmu harus menggunakan metode belajar dan pencarian kebenaran

${ }^{21}$ SoerjonoSoekanto, Pokok-Pokok Sosiologi Hukum, (Jakarta: Grafiti Pers. 1988), hlm. 5-6. 
yang teratur secara logis, dan ia mengetahuinya secara pasti melalui berbagai percobaan dan ujian, barulah sesuatu itu dapat disebut ilmu (Science). Zaprulkhan, mengutip Driyarkarya mengatakan ada perbedaan signifikan antara knowledge dengan Science. Ilmu tidak cukup hanya menetapkan kejadian-kejadian belaka atau memberikan penjelasan yang dangkal saja; ilmu berupaya mencari hubungan sebab-akibat, mencoba menentukan mengapa sesungguhnya kejadian-kejadian itu memang demikian. ${ }^{22}$

Disisi lain, dapat dikatakan baik pengetahuan dan ilmu (knowledge\&science) sama-sama memiliki makna mencari kebenaran, sebagai bagian dari usaha manusia untuk lebih mengerti tentang diri mereka sendiri. Tetapi, ada perbedaan yang signifikan, yaitu; Pengetahuan biasa tidak memandang betul-betul kausa sebab akibat dari suatu masalah dan tidak berusaha untuk mencari rumusan objektif secara radikal terhadap objek-objek yang diteliti dan ingin diketahui, tidak tersistem, tidak menggunakan metode dan tanpa proses sintesis. Sedangkan Ilmu sebaliknya; mementingkan sebab-akibat, mencari rumusan sebaik-baiknya, menyelidiki objeknya selengkap-lengkapnya secara radikal dengan tujuan untuk mencapai suatu sintesis; sistematis, logis, dapat diuji dan dipertanggungjawabkan secara ilmiah. ${ }^{23}$

Oleh karena itu, jika dikaitkan dengan pengetahuan hukum, pada dasarnya hampir setiap orang memiliki pengetahuan tentang hukum, tetapi hanya orang-orang tertentu saja yang memahami hukum sebagai ilmu. Setiap orang memiliki pengetahuan hukum karena mereka pernah terlibat dalam hukum, misalnya saat melakukan transaksi jual beli, mengurus akta kelahiran, mengurus KTP, dll. Jika mereka terlibat dalam satu proses hukum, maka biasanya orang tersebut akan mengetahui hukum. Tetapi orang yang memahami Ilmu Hukum haruslah mengikuti suatu proses belajar yang teratur, misalnya seorang Sarjana Hukum pada Fakultas Hukum. Mereka harus mempelajari hukum sebagai ilmu, walau mereka tidak pernah terlibat dalam suatu masalah hukum. Dalam belajar mereka mempelajarinya secara bertahap, sistematis, dibawah arahan para ahli dibidangnya, melakukan ujian dan penelitian dan seterusnya, sehingga mereka memperoleh pengetahuan sebagai orang yang memiliki penguasaan Hukum sebagai Ilmu. Dan apa yang mereka peroleh dari proses mempelajari hukum secara sistematis itu bukan hanya sebagai pengetahuan tetapi telah menjadi Ilmu.

Oleh karena itu, pada dasarnya kehadiran suatu ilmu berasal dari pengetahuan manusia. Sebagaimana yang kita singgung diatas, koleksi pengetahuan manusia itu cukup banyak dan luas. Pada tahap selanjutnya, kumpulan pengetahuan tersebut akan berpotensi menjadi ilmu ketika disusun secara sistematis. Pengetahuan baru bisa diubah menjadi ilmu apabila telah berhasil melewati enam tahap ujian atau enam komponen yang disebut dengan "six kind of science" yang meliputi; problems, attitude, method, activity, conclussion dan effects. Istilah "diuji" dalam ranah ilmu artinya bisa dibuktikan baik secara empiris mapun teoretis. ${ }^{24}$

${ }^{22}$ Zaprulkhan. Filsafat Ilmu Sebuah Analisis Kontemporer. (Jakarta: Rajawali Press, 2015), hlm. 14-15.

${ }^{23} \mathrm{Ibid}$. hlm. 15-16.

${ }^{24}$ Suwardi Endraswara. Filsafat Ilmu; Konsep, Sejarah, Dan Pengembangan Metode Ilmiah (edisi revisi). (Yogjakarta: CAPS., 2015), hlm. 66 
Sebagaimana dikemukakan diatas, untuk memahami Hukum sebagai Ilmu maka dia harus dikaji berdasarkan pendekatan Filsafat Ilmu untuk mendapatkan jawaban tentang; Objek apa yang ditelaah oleh ilmu? (Ontologis), Bagaimana proses yang memungkinkan ditimbanya pengetahuan? (Epistemologis) dan Untuk apa pengetahuan yang berupa ilmu pengetahuan itu dipergunakan? (Aksiologis). Semua pengetahuan apakah itu ilmu, seni, atau pengetahuan apa saja pada dasarnya mempunyai ketiga landasan ini. Yang berbeda adalah materi perwujudannya serta sejauh mana landasanlandasan dari ketiga aspek filsafat diatasdikembangkan dan dilaksanakan. Dengan demikian, maka kita dapat dengan mudah memahami konsep keilmuan hukum dari ketiga aspek filsafat tersebut di atas.

Di dalam perkembangannya, Ilmu Hukum memang selalu diperdebatkan legitimasinya sebagai "Ilmu". Perdebatan ini bukanlah perdebatan baru, tetapi sudah bersifat klasik, tetapi secara perlahan namun pasti Ilmu Hukum semakin hari semakin mengukuhkan eksistensinya sebagai bagian yang absah di dalam kerangka rumpun ilmu yang ada di dunia. Dasar perdebatan yang paling mendasar secara umum disebabkan faktor Ilmu Hukum yang memiliki karakter yang khas, yaitu sifatnya yang; normatif, praktis dan preskriptif. Karakter inilah yang menyebabkan sebagian kalangan yang tidak memahami kepribadian ilmu hukum itu mulai meragukan hakikat keilmuan hukum. Keraguan tersebut juga dikarenakan sifat normatif ilmu hukum membuatnya tidak bersifat empiris.

Dalam konteks penelitian ilmiah, secara umum, para sarjana hukum sering menyebut istilah Metode Penelitian Hukum Normatif dan Metode Penelitian Hukum Empiris-Sosiologis, sebagaimana mereka membedakan antara Kajian Ilmu Hukum Normatif dan Kajian Ilmu Hukum Empiris. ${ }^{25}$ Di Indonesia, penelitian hukum yang doktrinal terlanjur diberi label sebagai penelitian hukum normatif. Bahkan metode penelitian hukum kerap diidentikkan dengan metode penelitian normatif ini. Bernard Arief Sidharta, muncul dengan tulisannya, "Metode Penelitian Hukum Normatif" terpanggil untuk menjernihkan topik ini. Ia dengan lugas menjelaskan apa yang dimaksud dengan Penelitian Hukum Normatif itu. ${ }^{26}$ Mengutip, Sulistoyo, Bernard menjelaskan bahwa pembaca yang terbiasa dengan pemahaman bahwa metode penelitian hukum adalah metode penelitian dogmatika hukum, akan mengetahui secara mendalam langkahlangkah penalaran yang harus diperagakan oleh penstudi ilmu hukum dogmatis. Pendekatan sosiolegal pun dapat menerima tipe kajian seperti ini sebagai salahsatu ragam metodologis dalam penelitian hukum.

Adapun menurut Bernard Arief Sidharta sendiri di dalam makalahnya tersebut, Penelitian Hukum Normatif adalah jenis penelitian yang lazim dilakukan dalam kegiatan pengembangan Ilmu Hukum yang di Barat biasa disebut juga dengan Dogmatika Hukum (Rechtsdogmatiek). Mochtar Kusumaaatmaja menyebutnya Ilmu Hukum Positif, dan Philip Hadjon menyebutnya Ilmu Hukum Dogmatik, Ilmu Hukum Dogmatik atau Dogmatika Hukum.

\footnotetext{
${ }^{25}$ Bahder Johan Nasution, Metode Penelitian Hukum. (Bandung, 2008), hlm-74-82.

${ }^{26}$ Sulistyowati Irianto \& Sidharta; Dalam Pengantar Metode Penelitian Hukum, (Jakarta: Buku Obor). hlm. xiv-xv.
} 
Dengan demikian, Ilmu Hukum atau Dogmatika Hukum, kata Bernard Arief, adalah ilmu yang kegiatan ilmiahnya mencakup kegiatan menginventarisasi, memaparkan, menginterpretasi, dan mensistematisirdan juga mengevaluasi keseluruhan hukum positif (teks otoritatif) yang berlaku di dalam suatu masyarakat atau negara tertentu - dengan bersaranakan konsep-konsep (pengertian-pengertian), kategori-kategori, teori-teori, klasisfikasi-klasifikasi, dan metode-metode yang dibentuk dan dikembangkan khusus untuk melakukan semua kegiatan tersebut - yang keseluruhan kegiatan itu diarahkan untuk mempersiapkan upaya menemukan penyelesaian yuridik terhadap masalah hukum (mikro maupun makro) yang mungkin terjadi di dalam masyarakat. Jadi, Ilmu Hukum secara langsung terarah untuk menawarkan alternatif penyelesaian yuridik terhadap masalah hukum konkret. Alternatif yang ditawarkan itu dirumuskan dalam bentuk sebuah putusan hukum yang disebut juga proposisi hukum. Proposisi Hukum ini memuat penetapan tentang hak-hak dan kewajiban-kewajiban Subjek Hukum tertentu; artinya: memuat kaidah hukum.

Selanjutnya dikatakan bahwa Ilmu Hukum tersmasukkedalam kelompok IlmuIlmuPraktikal-Normologikal. Ilmu Praktikal adalah ilmu yang secara langsung mempelajari cara menemukan dan menawarkan alternatif penyelesaian terhadap masalah konkret. Sebagai Ilmu Praktikal, Ilmu Hukum termasuk jenis Normologikal, yakni Ilmu yang berupaya menemukan hubungan antara dua hal atau lebih berdasarkan asas imputasi (yakni menautkan tanggungjawab/kewajiban) untuk menetapkan apa yang seharusnya terjadi atau menjadi kewajiban subjek hukum tertentu dalam situasi konkret tertentu, sehubungan dengan terjadinya perbuatan atau peristiwa atau keadaan tertentu, walaupun dalam kenyataan apa yang seharusnya terjadi itu tidak niscaya dengan sendirinya terjadi, yang implementasi dan kepatuhannya dapat ditegakkan oleh otoritas publik. Metodenya disebut metode normatif atau yang menurut Soetandyo Woignyosoebroto disebut Metode Doktrinal. ${ }^{27}$

Berdasarkan beberapa penjelasan diatas, meski tidak begitu detil dapatlah kita pahami bahwa Ilmu Hukum pada dasarnya memiliki prasyarat-prasyarat Ilmiah untuk disebut sebagai ilmu dan dikembangkan dengan sebutan Ilmu Hukum. Kita tidak akan membahas terlalu detil mengenai perdebatan Hukum sebagai Ilmu, karena pada akhirnya memang kadar keilmiahan Ilmu Hukum diterima sedemikian rupa sebagai ilmu yang khas yang dan terus berkembang hingga sekarang. Menurut Phillipus M. Hadjon, Ilmu Hukm diterima sebagai Ilmu dengan tetap menghormati karakter Ilmu Hukum yang merupakan Kepribadian Ilmu Hukum. Dari sudut pandang karakter dan kepribadian, ilmu hukum dipandang sebagai suatu ilmu tersendiri (suigeneris). ${ }^{28}$

\section{3) Hukum Sebagai Suatu Sistim.}

Kajian yang paling mendasar dalam Sistim Hukum adalah menyangkut soal persamaan dan perbedaan antara beberapa Sistim Hukum yang diperbandingkan. Tentang

27 Bernard Arif Sidharta, "Penelitian Hukum Normatif: Analisis Penelitian Filosofikal dan Dogmatikal, dalam Sulistiyowati \& Sidharta, Ed., Metode Penelitian Hukum: Konstelasi dan Refleksi. (Jakarta: BukuObor. 2013). hlm. 142-149.

${ }^{28}$ Lihat Philipus M. Hadjon, Pengkajian Ilmu Hukum Normatif (normative), Yuridika, jurnal Hukum Universitas Airlangga Surabaya. No. 6 tahun IX, November-Desember 1994, hlm. 1 
hal ini Michael Bogdan mengatakan: Persamaan dan Perbedaan diantarasistim-Sistim Hukum adalah dua sisi mata uang yang sama. Persamaan menunjukkan kurangnya perbedaan, sementara perbedaan menunjukkan kurangnya persamaan. Karena itu, baik persamaan maupun perbedaan dipengaruhi oleh faktor yang-faktor yang sama, walaupun arahnya berlawanan. ${ }^{29}$

Tidak ada suatu difinisi yang jelas mengenai apa itu sistim hukum, dan makalah ini tidak akan membahas masalah yang rumit tersebut. Penulis mencoba memahami Sistim Hukum dengan pendekatan yang sangat sederhana, yaitu; bahwa sistim hukum dapat dilihat sebagai suatu kajian yang dengan pendekatan Analitis Mekanik atau Analitis Organis sebagaimana disinggung oleh Lili Rasjidi dalam bukunya Sistim Hukum Sebagai Suatu Sistim. ${ }^{30}$

Teori Sistim ini pada dasarnya adalah perkembangan dari pemikiran TalcotParsons yang mengembangkan Teori Struktural-Fungsional, yang meminjam pendekatan teori Sosiologi Klasik Emile Durkheim yang melihat masyarakat sebagai Suatu Sistim yang teratur yang saling berhubungan antara satu dengan yang lainnya, saling mempengaruhi untuk menciptakan suatu keseimbangan, guna mencapai tujuan dari sistim itu.

Pengertian ini juga dapat difahami sebagai Sistim Organik yang sebenarnya meminjam analogi Organisme tubuh manusia. Bahwa tubuh manusia adalah suatu sistim yang memiliki struktur, fungsi-fungsi dan tujuannya masing-masing untuk mendukung kebutuhan manusia itu secara keseluruhan. Jika hal ini dilihat dalam konteks hukum sebagai suatu sistim, maka hukum itu adalah suatu sistim hukum yang memiliki subsistem hukum, yang saling berhubungan antara satu dengan yang lainnya, dalam suatu keseimbangan dimana struktur hukum dan fungsi hukum mendukung tujuan dari diciptakannya hukum. ${ }^{31}$

Di dunia ini ada beberapa Sistim Hukum yang berbeda yang dipraktikkan atau dianut oleh seluruh bangsa-bangsa di dunia. Para Ahli berbeda-beda pula pandangannya tentang Sistim Hukum apa saja yang sebenarnya dianggap sebagai sistim-sistim Hukum tersebut. Ada yang membeda-bedakannya sebagai Sistim Hukum menurut negara yang mempraktikkan, misalnya Michael Bogdan, menganggap ada Sistim Inggris, Sistim Jerman, Sistim Perancis, Sistim Amerika, Sistim Cina, Sistim Sosialis dan Sistim Islam. ${ }^{32}$ Pembedaan dengan cara ini dilakukan oleh Michael Bogdan karena menganggap bahwa meskipun aliran pemikiran yang melatarbelakangi suatu Sistim Hukum itu sama, tetapi dalam praktiknya di masing-masing negara membuat Sistim Hukum itu menjadi khas sebagai sistim di negara tersebut. Cara pembedaan ini sangat terlihat jelas setelah membaca keseluruhan buku tersebut.

Umumnya ahli hukum membedakan Sistim Hukum berdasarkan aliran Pemikiran Hukum dan Prinsip Hukum yang dianut. Salah satunya adalah Zainal Asikin dalam bukunya Pengantar Tata Hukum Indonesia, yang menyebutkan bahwa Sistim Hukum itu

29 Michael Bogdan, Pengantar Perbandingan Sistim Hukum., (Jakarta: Nusamedia, 2010), hlm 77-78.

${ }^{30}$ Lili Rasjidi, Hukum Sebagai Suatu Sistim. (Bandung: Fika Hati Semesta, 2012), hlm. 20.

${ }^{31}$ George Ritzer \& Douglas J. Goodman, Teori Sosiologi Modern, (Jakarta: Kencana, 2004), hlm. 115-116.

${ }^{32}$ Ibid. 
terdiri dari; Sistim Hukum Civil Law, Sistim Hukum Common Law, Sistim Hukum Sosialis, Sistim Hukum Islam, dan Sistim Hukum Masyarakat Eropa.

Perumusan ini berbeda lagi dengan apa yang ditulis oleh Ade Maman Suherman di dalam bukunya Pengantar Perbandingan Sistim Hukum yang menyebutkan bahwa Sistim Hukum itu terdiri dari; Sistim Hukum Civil Law, Common Law dan Hukum Islam. ${ }^{33}$ Masih banyak lagi perbedaan sudut pandang dalam merumuskan apa saja sebenarnya yang masih bisa disebut sebagai Sistim Hukum. Misalnya, para Sarjana Hukum di Indonesia, terutama paska Kemerdekaan selalu menyebut Sistim Hukum Adat (Adatrecht) sebagai satu jenis Sistim Hukum Tersendiri. ${ }^{34}$

Intinya; Ada banyak sistim hukum di dunia yang mempengaruhi Sistim Hukum di suatu negara, hingga sampai pada bentuk dan model praktik-praktik hukum secara lebih khusus, baik di dalam Hukum Pidana, Hukum Perdata, Hukum Tata Negara. Bahkan Perbedaan Sistim Hukum ini tidak hanya berpengaruh terhadap Model dan Praktik Hukum secara umum, tetapi juga di dalam Model Penyelesaian Konflik. Tetapi hampir mayoritas Pemikir Hukum di dunia sepakat bahwa Sistim Hukum yang paling berpengaruh ada dua, yaitu; Sistim Hukum Civil Law dan Sistim Hukum Common Law.

Negara Indonesia sendiri adalah salah satu negara di dunia yang menganut Sistim Hukum Eropa Kontinental yang biasa disebut dengan Civil Law atau Hukum Sipil yang memiliki latar belakang sejarah sangat panjang sejak zaman Romawi (Abad-V M). Selain Indonesia, Civil Law saat ini dipraktikkan pada sebagian besar negara Eropa Barat seperti Italia, Jerman, Perancis, Belgia, juga umumnya negara-negara Amerika Latin, Timur Dekat, Sebagian besar Afrika, Indonesia dan Jepang.

Dalam Sistim Hukum Civil Law, istilah "code" (Undang-Undang) adalah sekumpulan klausula dan prinsip hukum umum yang otoritatif. Komprehensif dan sistematis yang dimuat dalam Kitab atau Bagian yang disusun secara logis sesuai dengan hukum terkait. Oleh sebab itu, peraturan Civil Law dianggap sebagai sumber hukum yang utama, dimana semua sumber hukum lainnya menjadi sub-ordinatnya.Sedangkan dalam Sistim Hukum Common Law, meskipun dijumpai penggunaan istilah "code" untuk peraturan hukum, akan tetapi makna peraturan hukum itu tidak termuat dalam kitab undang-undang yang komprehensif itu, peraturan itu hanya bersifat terbatas, baik lingkup pengaturannya maupun wilayah berlakunya.

\section{4) Struktur Ilmu Hukum dalam Rumpun Ilmu Hukum.}

Sebagaimana telah disinggung pada penjelasan-penjelasan sebelumnya, dan juga literatur-literatur hukum yang terdapat diperpustakaan, ada tiga cabang besar pembagian ilmu hukum dalam Sistim Hukum Eropa Kontinental, sebagaimana dianut oleh Negara Republik Indonesia, yakni; Ilmu Hukum Pidana, Ilmu Hukum Perdata dan Ilmu Tata Negara. Masing-masing cabang ini memiliki bagian-bagiannya tersendiri sebagai komponen yang lebih kecil dari suatu sistim hukum yang lebih besar.

\footnotetext{
${ }^{33}$ Ade Maman Suherman, Pengantar Perbandingan Sistim Hukum. (Jakarta: Rajawali Pers, 2012), hlm. 3

${ }^{34}$ C.S.T. Kansil, Pengantar Ilmu Hukum. (Jakarta: PradnyaParamita, 2009), hlm. 15.
} 
Secara konseptual, Menurut Bernard Arief Sidharta, mengutip Mochtar Buchori, pada dasarnya keseluruhan ilmu itu dibagi kedalam dua kelompok besar, yakni Ilmu Teoritis dan Ilmu Praktis. Ilmu Teoritis bertujuan untuk memperoleh atau mengubah pengetahuan. Sedangkan Ilmu Praktis bertujuan untuk mengubah keadaan. Ilmu teoritis terdiri atas Ilmu Formal dan Ilmu Empiris. Ilmu formal menghasilkan struktur murni, seperti struktur logika, skema, jaringan, sistim perhitungan. Ilmu Empiris merupakan interpretasi terhadap Ilmu Formal yang diproyeksikan pada aspek tertentu dari dunia kenyataan. Ilmu Empiris terdiri dari atas kelompok Ilmu Alam dan Kelompok Ilmu Manusia, yang terdiri atas Ilmu Sejarah dan Ilmu Sosial. Ilmu Praktis merupakan hasil evaluasi terhadap (produk) Ilmu Empiris dan Ilmu Formal untuk digunakan menghadapi dan menyelesaikan masalah yang dihadapi manusia dalam kenyataan kehidupan. Dengan demikian, Ilmu Praktis ini merupakan medan tempat berbagai ilmu bertemu dan berinteraksi (berkonvergensi), yang produk akhirnya berupa penyelesaian masalah yang secara ilmiah (rasional) dapat dipertanggungjawabkan. Ilmu Praktis sendiri terdiri atas Ilmu Praktis Nomologis dan Ilmu Praktis Normologis. (Adapun pengertian Nomologis dan Normologis dijelaskan pada bagian lain makalah ini). Antara berbagai jenis ilmu ini terdapat hubungan saling memberikan dan menerima umpan balik.

Dengan demikian jelaslah kini dimana posisi Ilmu Hukum dalam kerangka rumpun ilmu. Sebagai Ilmu Praktis-Normologis, Ilmu Hukum menduduki tempat yang khusus antara Ilmu Teoritis dengan Ilmu Empiris. Sebagai Ilmu Praktis-Normologis yang menjadi medan konvergensi atau medan pertemuan berbagai masalah kehidupan manusia sehari-hari Ilmu Hukum dengan sendirinya bertemu dengan Disiplin Ilmu-Ilmu Lainnya, seperti sosiologi, antropologi, ekonomi, politik dan lain-lain. Hal ini sesuai dengan istilah bahwa Ilmu Hukum pada dasarnya adalah "ilmu bersama". Inilah salahsatu keunikan dan kekhasan Ilmu Hukum.

Sidharta lebih lanjut mengemukakan bahwa dengan begitu banyaknya keterlibatan disiplin ilmu-ilmu lain yang mempelajari hukum sebagai pokok studinya dari sudut pandang masing-masing, mendorong orang untuk melakukan "sistematisasi" . Meuwissen, misalnya, sebagaimana Sidharta, menggunakan istilah "pengembanan hukum" (rechtsbeoefening) untuk menunjuk semua kegiatan manusia berkenaan dengan adanya dan berlakunya hukum di dalam masyarakat. Meuwissen menata berbagai disiplin hukum itu berdasarkan tataran analisisnya terhadap tingkat abstraksi ilmu tersebut. Berdasarkan analisisnya, dibedakan tiga jenis pengembanan Hukum Teoritis.

Disiplin hukum yang tingkat abstraksinya paling rendah, yakni pada tataran Ilmu Positif disebut; Ilmu Hukum Dogmatik (yaitu Ilmu Hukum dalam arti sempit) yang terdiri dari; Sejarah Hukum, Perbandingan Hukum, Sosiologi Hukum dan Psikologi Hukum. Disiplin Ilmu Hukum pada tataran yang lebih abstrak disebut Teori Hukum. Pada tataran yang tingkat abstraksinya lebih tinggi, yakni pada tataran kefilsafatan, disiplinnya disebut Filsafat Hukum yang meresapi semua bentuk pengembanan Hukum Teoritis dan Praktis. Meuwissenmengggunakan istilah Ilmu Hukum dalam arti luas yang mencakup semua pengembanan Hukum Teoritis pada tataran Ilmu Positif. Untuk Ilmu Hukum dalam arti sempit, ia menggunakan istilah yang sudah lazim di Barat, yakni Dogmatika Hukum (rechtsdogmatiek, Legal Dogmatic). 
Jika dikatakan bahwa Ilmu Hukum yang kita pelajari di sekolah-sekolah hukum, khususnya di Indonesia adalah Ilmu Praktis-Normologis, maka jelaslah bahwa cabangcabang ilmu hukum sebagaimana yang kita pelajari pembagiannya dalam Mata Kuliah Dasar (MKD) Hukum seperti Hukum Pidana, Hukum Perdata dan Hukum Tata Negara itu termasuk dalam Ilmu Praktis-Normologis, yaitu pengetahuan tentang Ilmu Hukum yang bisa ditemukan pada Mata Kuliah Ilmu Hukum Pengantar Ilmu Hukum (PIH) dan pengetahuan tentang Hukum Indonesia yang bisa didapatkan melalului mata kuliah Pengantar Hukum Indonesia (PHI).

Kedua mata kuliah tersebut merupakan Mata Kuliah Dasar Hukum (MKH) dengan bobot yang tinggi. Setiap mahasiswa Fakultas Hukum yang akan mempelajari Ilmu Hukum Wajib mempelajari mata kuliah tersebut dengan nilai terbaik. Setelah melewati mata kuliah wajib, khususnya kedua mata kuliah tersebut, barulah setiap mahasiswa dapat memperdalam konsentrasi disiplin Ilmu Hukumnya berdasarkan konsentrasi, baik Perdata, Pidana atau Tata Negara. ${ }^{35}$ Terkait dengan kajian dari makalah yang sedang kita bahas ini, seperti yang telah diutarakan sebelumnya, kita akan memfokuskan analisis pada posisi Ilmu Hukum Tata Negara, bukan Hukum Pidana dan bukan pula Hukum Perdata atau Hukum Administrasi negara. Dengan demikian sampailah kita pada ranah Hukum Tata Negara.

\section{5) Ilmu Negara sebagai Dasar Ilmu Hukum Tata Negara.}

Dalam penelusuran penulis, ternyata Ilmu Hukum Tata Negara tidak serta merta terbentuk menjadi cabang atau rumpun dari Ilmu Hukum sebagai Ilmu PraktisNormologis. Menurut Ni'matul Huda, yang melakukan analisis terhadap penjelasan George Jellinek mengenai kerangka Ilmu Negara dan hubungannya dengan Ilmu Tata Negara, bahwa Ilmu Negara merupakan suatu pelajaran pengantar dan ilmu dasar pokok bagi pelajaran Hukum Tata Negara. Oleh karena itu Hukum Tata Negara tidak dapat dipelajari secara ilmiah dan teratur sebelum terlebih dahulu dipelajari pengetahuan tentang pengertian-pengertian pokok dan sendi-sendi dari negara secara umum. Hal ini selaras dengan perumusan pengertian dari Ilmu Negara itu sendiri, yaitu; "merupakan ilmu pengetahuan yang menyelidiki pengertian-pengertian pokok dan sendi-sendi pokok negara".

Ilmu Negara dapat memberikan dasar-dasar teoritis untuk Hukum Tata Negara yang positif. Hukum Tata Negara merupakan penerapan atau penyerapan di dalam kenyataan-kenyataan konkrit dari bahan-bahan teoritis yang dihasilkan oleh Ilmu Negara. Karenanya Ilmu Hukum Tata Negara itu mempunyai sifat praktis sebagai ilmu terapan atau ilmu praktis (appliedscience) yang bahan-bahannya diselidiki, dikumpulkan dan disediakan oleh ilmu teoritis (pure science) Ilmu Negara. ${ }^{36}$

Untuk lebih jelasnya marilah kita ikuti penjelasan dari George Jellinek sendiri sebagaimana ditulisnya dalam buku; AllgemineStaatslehre (Ilmu Kenegaraan) atau

\footnotetext{
${ }^{35}$ Lihat Kurikulum setiap Prodi Fakultas Hukum yang ada di universitas Indonesia. Secara lebih khusus Kurikulum Fakultas Hukum Universitas Syiah Kuala, Darussalam, Banda Aceh, tahun ajaran 2015-2016.

${ }^{36}$ Ni’matul Huda. Ilmu Negara. (Jakarta: Rajawali Press, 2012), hlm.7-9
} 
disingkat disebut dengan Staatslehre; secara garis besar menggambarkannya sebagai berikut;

Pertama-tama Jellinek membagi Staatslehre (Ilmu Negara) menjadi dua, yaitu;

1. Ilmu Negara dalam arti sempit (Staatswissenssschaft); dan

2. Ilmu Negara dalam arti luas (Rechtswissenschaft); Yang dimaksud adalah; hukum publik yang menyangkut soal kenegaraan, misalnya Hukum Tata Negara, Hukum Administrasi Negara, Hukum Pidana dan sebagainya.

Tetapi yang menjadi perhatian khusus Jellinek adalah Ilmu Negara dalam arti sempit. Kemudian "Staaswissenschaft" dalam pengertian sempit ini dibagi dua lagi menjadi;

a. Algemeine Staatslehre (Ilmu Negara Umum).

b. Besondere Staatslehre (Ilmu Negara Khusus).

Kemudian "Algemeine Staatslehre" ini berkembang menjadi "Teoretische Staatswissenschaft" (Teori Ilmu Negara dalam arti sempit) yang kemudian dibagi dua lagi, yaitu;

i) Algemeine Soziale Staatslehre; rumpun ini ini menyelidiki negara sebagai gejala sosial dan dapat disamakan dengan, misalnya; perkumpulan-perkumpulan sosial. Intinya adalah, pada penekanan sifat sosial daripada negara.

ii) Algemeine Staatsrechtlehre; rumpun ini menyelidiki negara dari segi juridis.

Sementara itu "Besondere Staatslehre" dibagi menjadi;

a. Individuele Staatslehre: Rumpun ini penyelidikannya ditujukan kepada suatu negara tertentu yang kongkrit, misalnya; Negara Indonesia, Negara Inggris, Negara Amerika Serikat dan sebagainya. Kemudian dari masing-masing negara tersebut dipelajari lagi lembaga-lembaga kenegaraannya, misalnya; Badan Eksekutif, Badan Legislatif, Badan Judikatif dan kelembagaan negara lainnya.

b. Spezielle Staatslehre: Rumpun ini penyelidikannya ditujukan kepada negara dalam pengertian yang umum, dan kemudian dari negara dalam pengertiannya yang umum itu dipelajari lagi lebih lanjut lembaga-lembaga kenegaraannya yang khusus atau spesial, misalnya; khusus mempelajari lembaga perwakilannya. ${ }^{37}$

Jika kita mengikuti skema yang digambarkan Jellinekdiatas, maka dengan cepat kita dapat mengenali bahwa Hukum Tata Negara adalah Ilmu Praktis-Normologis yang lebih praktis dari Ilmu Negara dalam arti sempit (Staatswissenschatf), dan lebih khusus lagi (Besondere Staatsrechtlehre). Sebagai Ilmu Negara yang khusus, maka Hukum Tata Negara yang membahas aspek tertentu yang khusus seperti Konstitusi Suatu Negara dapatlah dikatakan sebagai; "Individuelle Staatslehre", atau Hukum Tata Negara yang secara khusus membahas tentang Hukum Tata Negara di Indonesia. Sampai disini jelaslah sudah posisi Ilmu Hukum Tata Negara yang kita maksudkan di dalam makalah ini, yang ternyata tidak bisa dipisahkan dengan Ilmu Negara. Sekadar catatan, bahwa saat menyebut Hukum Tata Negara disini, sejauh mengenai objek negara, dianggap satu paket dengan Hukum Tata Pemerintahan, demikian Jellinek.

${ }^{37}$ Soehino, Ilmu Negara. (Yogjakarta: Liberty, 2008), hlm. 9-10. 


\section{6) Kajian Negara Hukum Pancasila dalam Rumpun Ilmu Hukum.}

Selanjutnya, sesuai dengan salah satu persoalan yang ingin dijawab oleh makalah ini, penulis ingin mendekati posisi Ilmu Hukum Tata Negara di Indonesia dalam konteks rencana penelitian Disertasi dengan judul: "Paradigma Negara Hukum Pancasila dan implikasinya terhadap Sistim Hukum di Indonesia" yang merupakan satu kegiatan terpisah. Penulis ingin menjelaskan dimanakah posisi kajian ini dalam kerangka rumpun Ilmu Hukum itu sendiri. Oleh karena ituperlu secara jelas mengidentifikasi posisi Kajian tentang Negara Hukum Pancasila Dalam Kerangka Rumpun Ilmu, khususnya Ilmu Hukum Tata Negara, dalam konteks Indonesia atau Tata Hukum di Indonesia.

Jika diperhatikan judul kajian diatas, terdapat tiga variabel, yaitu; Variabel Paradigma, variable Negara Hukum dan Variabel Pancasila. Variabel utama dalam hal ini adalah: Negara Hukum (v1), sedangkan Paradigma adalah variabel Pendukung (v2) dan Pancasila adalah Variabel Tergantung (v3).

Untuk lebih memahami hubungan antara kajian rumpun ilmu ini dengan pokokpokok permasalahan yang menjadi fokus perhatian penulis di dalam kajian tersebut perlu dijelaskan beberapa hal berikut; Pertama; kajian tersebut ingin menjawab; Apakah Paradigma Negara Hukum Pancasila Pasca Amandemen Konstitusi UUD-1945? (Yang ingin dihasilkan dari pertanyaan ini adalah Deskripsi Kerangka Konseptual Negara Hukum Indonesia pasca-amandemen Konstitusi, khususnya setelah dihilangkannya penjelasan "Rechstaat" yang sebelumnya ditulis dalam tanda kurung pada pasal Konstitusi).

Kedua; Apakah implikasi Paradigma Negara Hukum Pancasila terhadap Sistim Hukum di Indonesia? (Yang ingin dihasilkan dari pertanyaan ini adalah; Deskripsi dampak perubahan Konsep Negara Hukum Indonesia, terhadap Sistim Hukum Indonesia maupun Sistim Ketatanegaraan Indonesia; yang secara konseptual ingin penulis usulkan agar menjadi "Negara Hukum-Pancasila" secara formal).

Ketiga; Apakah implikasi Paradigma Negara Hukum Pancasila terhadap Sistim Perundang-Undangan di Indonesia? (Yang ingin dihasilkan dari pertanyaan ini adalah Deskripsi Dampak perubahan Paradigma Negara Hukum Pancasila terhadap Sistim Perundang-Undangan di Indonesia).

Adapun tujuan penulisannya antara lain, merumuskan paradigma Negara Hukum Pancasila dalam sistim Hukum Indonesia, paska-amandemen UUD-1945; Menjelaskan implikasi Konsep Negara Hukum Pancasila dalam Sistim Hukum Indonesia, PaskaAmandemen UUD-1945; dan menjelaskan Perkembangan Sistim Hukum Indonesia berdasarkan Konsepsi Negara Hukum Pancasila, paska-amandemen UUD- 1945.

Dari penjelasan sekilas diatas, kiranya telah dapat memberikan petunjuk kepada kita bahwa kajian ini termasuk ke dalam Hukum Tata Negara. Tetapi karena kajian HTN itu luas maka harus dilihat lagi apakah objek pembahasan dalam kajian Negara Hukum tersebut. Dalam hal ini kajiannya adalah terkait dengan substansi Pasal 1 (3) konstitusi yang berbunyi; Indonesia adalah negara hukum. Dengan demikian, sudah jelas bahwa basis kajian ini adalah Konstitusi, dan yang menjadi pembahasan adalah norma Pasal 1 (3) konstitusi. Dengan demikian, kita sudah memasuki wilayah Hukum Konstitusi. 
Mengenai hal ini, apa yang dikatakan oleh JimlyAsshiddiqie, mengutip Djokosoetono,sangat tepat dengan kerangka pikir penulis, mengenai dimanakah posisi kajian tersebut di atas di dalam rumpun Ilmu Hukum Tata Negara kita. Menurut pendapat Jimly, bahwa ke dalam Hukum Tata Negara itu memang harus dimasukkan pula faktor konstitusi sebagai objek kajian yang pokok. Konstitusi, baik dalam arti materiel, formil, administratif, ataupun tekstual dalam arti collectiveminds ataupun dalam arti civicbehaviouralrealities, adalah pusat perhatian yang sangat penting dari Ilmu Hukum Tata Negara atau the study oftheconstitutionallaw. Konstitusi yang dijadikan objek kajian itu dapat mencakup tiga pengertian, yaitu;

1. Constitutie in materielezin, yang dikualifikasi karena isinya, misalnya berisi jaminan hak asasi, bentuk negara, dan fungsi-fungsi pemerintahan, dan sebagainya.

2. Constitutie in formelezin yang dikualifikasikan karena pembuatnya, misalnya oleh MPR; atau,

3. Konstitusi dalam arti naskah grondwet sebagai gesrechvendocument, misalnya, harus diterbitkan dalam Lembaran Negara, supaya dapat menjadi alat bukti dan menjamin stabilitas satu kesatuan sistem rujukan.

Lebih lanjut dikatakan, konstitusi yang dijadikan objek kajian itu dapat berupa nilai-nilai dan norma yang terkandung di dalam teks konstitusi itu sendiri, ataupun nilainilai dan norma yang hidup dalam kesadaran kognitif atau collectiveminds dan perilaku segenap warganegara (civicbehaviour). Oleh karena itu, menurut Jimly, hukum tata negara itu haruslah diartikan sebagai hukum dan kenyataan praktik yang mengatur tentang:

1. Nilai-nilai luhur dan cita-cita kolektif rakyat suatu negara;

2. Format kelembagaan organisasi negara;

3. Mekanisme hubungan antarlembaga negara; dan

4. Mekanisme hubungan antara lembaga negara dengan warga negara.

Dengan demikian, Ilmu Hukum Tata Negara dapat dirumuskan sebagai cabang Ilmu Hukum yang mempelajari prinsip-prinsip dan norma-norma hukum yang tertuang secara tertulis ataupun yang hidup dalam kenyataan praktik kenegaraan berkenaan dengan; (i) konstitusi yang berisi kesepakatan kolektif suatu komunitas rakyat mengenai cita-cita untuk hidup bersama dalam suatu negara; (ii) institusi-institusi kekuasan negara beserta fungsi-fungsinya; (iii) mekanisme hubungan antar-institusi itu; serta (iv) prinsipprinsip hubungan antara institusi kekuasaan negara dengan warganegara. Keempat unsur dalam definisi Hukum Tata Negara tersebut di atas pada pokoknya, adalah hakikat konstitusi itu sendiri sebagai objek utama kajian Hukum Tata Negara (constitutionallaw). ${ }^{38}$

Dengan demikian jelaslah bagi kita, bahwa pada dasarnya kajian; "Paradigma Negara Hukum Pancasila dan Implikasinya Terhadap Sistim Hukum di Indonesia", merupakan kajian Ilmu Hukum Normatif dalam sistim Hukum Eropa Continental, dan masuk ke dalam Cabang Ilmu Hukum Tata Negara, dalam hal ini termasuk dalam kajian konsitusi yang juga dapat dikatakan dengan Hukum Konstitusi (constitutionallaw).

\footnotetext{
${ }^{38}$ Jimly Asshiddiqie, Pengantar ... Op., Cit, hlm. 29-30.
} 


\section{Penutup}

Berdasarkan kajian yang telah dilakukan di dalam makalah ini, dengan menggunakan kerangka metodologi yang tepat dan sesuai dengan kebutuhan pembedahan terhadap latarbelakang masalah serta pendekatan yang harmonis dengan kerangka teori serta tujuan penulisan, maka penulis mencoba menyusun suatu kesimpulan. Adapun proses pengambilan kesimpulan ini dilakukan secara sistematis dengan menggunakan logika bersifat deduktif, sehingga mencapai suatu titik dimana pembahasan diatas mencapai suatu kesimpulan. Adapun kesimpulan tersebut antara lain;

A. Bahwa Hukum adalah Ilmu, yang disebut dengan Ilmu Hukum, bukan hanya sekadar pengetahuan. Sebagai Ilmu, maka Hukum memiliki metodologi dan struktur tersendiri.

B. Bahwa Ilmu Hukum adalah Ilmu Praktis-Normologis. Maka sebagai Ilmu Praktis-Normologis. Ilmu hukum bersifat khas, meskipun ia merupakan ilmu yang praktis, yang artinya digunakan untuk menyelesaikan masalah praktis, tetapi ia juga berupa ilmu yang bersifat normatif. Sehingga semua penelitian hukum pada dasarnya bersifat normatif, meskipun didalamnya terdapat sifat empiris, seperti Ilmu Antropologi, Ilmu Politik dan Ilmu Sosiologi, tetapi sifatnya hanya membantu.

C. Bahwa Kajian: "Paradigma Negara Hukum dan Implikasinya terhadap Sistim Hukum di Indonesia" termasuk kedalam kajian Ilmu Hukum Tata Negara yang terkait dengan Ilmu Negara dan masuk dalam konsentrasi Ilmu Hukum Konstitusi, karena yang dikaji didalamkajian tersebut berbasis telaah terhadap Konstitusi dengan tema tentang Negara.

D. Bahwa Kajian yang sedang dilakukan penulis dengan judul : Paradigma Negara Hukum Pancasila, termasuk ke dalam kajian Hukum Konstitusi. Sehingga posisinya adalah merupakan Rumpun Ilmu Hukum Tata Negara, Cabang dari Ilmu Hukum, dan merupakan bagian dari Ilmu Tata Negara Yang Individual, yaitu Hukum Konstitusi.

\section{Daftar Pustaka}

\section{Buku:}

Ade Maman Suherman, Pengantar Perbandingan Sistim Hukum, Rajawali Pers, Jakarta, 2012

Aristoteles, Politik, Buku Seru, Bandung, 2016

Bahder Johan Nasution, Metode Penelitian Hukum, Bandung, 2008

Bernard Arief Sidharta, Refleksi Tentang Struktur Ilmu Hukum (Disertasi), Mandar Maju, Bandung, 2000

George Ritzer \& Douglas J. Goodman, Teori Sosiologi Modern, Kencana, Jakarta, 2004 
Jimly Asshiddiqie. Pengantar Ilmu Hukum Tata Negara, Rajawali Press, Jakarta, 2013

Jujun. S. Suriasumantri, Filsafat Ilmu Sebuah Pengantar Popular, Sinar Harapan. Jakarta, 2005

Kansil C.S.T., Pengantar Ilmu Hukum dan Tata Hukum Indonesia, Balai Pustaka, Jakarta, 1989

Pengantar Ilmu Hukum, Pradnya Paramita, Jakarta, 2009

Lili Rasjidi, Hukum Sebagai Suatu Sistim. Fika Hati Semesta, Bandung, 2012

Michael Bogdan, Pengantar Perbandingan Sistim Hukum, Nusamedia, Jakarta, 2010

Ni’matul Huda. Ilmu Negara, Rajawali Press, Jakarta, 2012

Philipus M. Hadjon, Pengkajian Ilmu Hukum Normatif (normative), Yuridika, jurnal Hukum Universitas Airlangga Surabaya. No. 6 tahun IX, November-Desember 1994

Soehino, Ilmu Negara, Liberty, Yogjakarta, 2008

Ilmu Negara, Liberty, Yogyakarta, 2002

Soerjono Soekanto, Pokok-Pokok Sosiologi Hukum, Grafiti Pers, Jakarta, 1988

Soeroso. Pengantar Ilmu Hukum, Sinar Grafika, Jakarta, 2011

Soetomo, Masalah Sosial dan Upaya Pencegahannya, Pustaka Pelajar, Yogjakarta, 2008

Sulistiyowati \& Sidharta, Ed., Metode Penelitian Hukum: Konstelasi dan Refleksi, Buku Obor. Jakarta, 2013

Susanto A., Filsafat Ilmu: Suatu Kajian Dalam Dimensi Ontologis, Epistemologis dan Aksiologis. Bumi Aksara, Jakarta, 2011

Suwardi Endraswara. Filsafat Ilmu; Konsep, Sejarah, Dan Pengembangan Metode Ilmiah (edisi revisi), CAPS., Yogjakarta, 2015

Valerine JLK., Metode Penelitian Hukum, Diktat Kuliah Pascasarja, Fak. Hukum UI, 2009, (Untuk kalangan sendiri, tidak diperjual belikan), 2009

Van Appeldorn, Pengantar Ilmu Hukum (inleiding tot de studie van het nederlandserecht), (Terjemahan Mr. Oetarid Sadino). Pradnya Paramita, Jakarta, 2011

Zainal Asikin, Pengantar Tata Hukum Indonesia. Rajawali Press, Jakarta, 2013

Zaprulkhan. Filsafat Ilmu Sebuah Analisis Kontemporer, Rajawali Press, Jakarta, 2015 
Volume 13, Nomor 1, Januari-Juni 2018

\section{Internet:}

http://www.panarchy.org/vonbertalanffy/systems.1968.html.

https://en.wikipedia.org/wiki/Systems_theory 